\title{
Diagnostic assays in cytomegalovirus retinitis: detection of herpesvirus by simultaneous application of the polymerase chain reaction and local antibody analysis on ocular fluid
}

The Eye Hospital, Rotterdam P Doornenbal G S Baarsma

Department of Virology, University Hospital Dijkzigt, Rotterdam P H Rothbarth H G M Niesters

Department of Molecular Biology, Diagnostic Center SSDZ, Delft W G V Quint

The Netherlands Ophthalmic Research Institute, Amsterdam A Kijlstra

Correspondence to: P Doornenbal, MD, The Eye Hospital, PO Box 70030 , 3000 LM Rotterdam, the Netherlands.

Accepted for publication 13 September 1995

Peter Doornenbal, G Seerp Baarsma, Wim G V Quint, Aize Kijlstra, Philip H Rothbarth, Hubert G M Niesters

\begin{abstract}
Aim-To determine the value of the polymerase chain reaction (PCR) technique and the analysis of intraocularly produced antibodies by calculating a GoldmannWitmer quotient (GWq) as diagnostic assays in the confirmation of a clinically diagnosed cytomegalovirus (CMV) retinitis in a group of unselected AIDS patients. Methods-Eleven samples of undiluted ocular fluid, obtained from nine AIDS patients with a clinically diagnosed CMV retinitis were analysed for the presence of genomic DNA from CMV, HSV-1, VZV, and EBV by PCR. Nine of these samples were analysed for the presence of locally produced IgG antibodies against these herpesviruses by calculating a GWq. Ten samples obtained from patients with various entities of clinical non-herpetic uveitis and 17 samples of aqueous humour obtained at cataract surgery were used as controls.
\end{abstract}

Results-In 10 out of 11 samples from AIDS patients $(91 \%)$ the presence of $\mathrm{CMV}$ DNA was demonstrated. In four out of nine $(44 \%)$ patients this was accompanied by CMV DNA in the blood indicating a CMV viraemia. In one sample, VZV DNA was detected and in another sample both CMV and VZV DNA were detected. No HSV-1 or EBV DNA could be demonstrated in these 11 samples. In contrast, simultaneous analysis of locally produced IgG antibodies against herpesviruses could not confirm the initial diagnosis of CMV retinitis. Ocular fluid samples obtained from 10 control uveitis patients were negative for DNA from CMV, VZV, and EBV by PCR. In one of 10 uveitis control samples HSV-1 DNA was detected; antibody analysis did not confirm this. In the uveitis control group, a significant GWq was calculated in one sample for HSV-1 and in another sample for VZV. The cataract control samples were all herpesvirus DNA negative by PCR. Conclusions-To establish the diagnosis of CMV retinitis in AIDS patients, ophthalmoscopic examination is a sensitive method. In confirming a diagnosis in indistinctive cases, application of a PCR assay detecting CMV DNA is a more sensitive method than analysis of locally produced antibodies by calculating a GWq. In clinical non-herpetic uveitis, secondary release of $\mathrm{HSV}-1$ and VZV should be considered requiring additional therapeutic anticipation.

(Br f Ophthalmol 1996; 80: 235-240)

Cytomegalovirus (CMV) has been recognised as a causative agent in the diagnosis of uveitis by virus culture for 35 years. ${ }^{1} \mathrm{CMV}$ retinitis mainly affects immunocompromised patients and predominantly AIDS patients. ${ }^{2-8}$ Only three cases of CMV retinitis have been reported in apparently healthy individuals. 6910

Clinically, the patients' main complaints are blurred vision, scotoma, and progressive impaired visual acuity, but asymptomatic ocular infections also occur. The extent of the symptoms depends on the location and type of tissue damaged by the inflammatory reaction. 5611 Early ophthalmoscopic findings include diffuse granular infiltrates that may mimic cotton wool spots. Later, typical granular haemorrhagic lesions with centrifugal spread, yellow white perivascular infiltrates, retinal oedema, and vascular sheathing can occur. ${ }^{211}$ Finally, atrophy of the affected retina and the pigment epithelium and fibrosis may become apparent.

In most cases the diagnosis of CMV retinitis is based on clinical examination and findings by ophthalmoscopy which are typical but not always specific. The differential diagnosis of CMV retinitis should include non-infectious cotton wool spots, toxoplasmosis, candidiasis, syphilis, herpes simplex virus (HSV-1), and varicella zoster virus (VZV) retinitis. $^{812}$ In AIDS patients, the diagnosis can be masked by multiple agents co-infecting the retina. For an adequate choice of therapy confirmation of the clinical diagnosis of CMV retinitis by laboratory tests might be required. ${ }^{3} 13$

Conventional culture of CMV from blood, 
aqueous, or vitreous fluid can take a long time to grow and it is rarely positive, limiting its consequences for treatment. ${ }^{25} \mathrm{~A}$ positive blood culture, however, can be helpful in establishing a disseminated CMV infection, which is accompanied by CMV retinitis in $22-48 \%$ of AIDS patients. ${ }^{411} 14$

The most sensitive method in antibody production analysis in uveitis patients, is calculation of a Goldmann-Witmer quotient (GWq). ${ }^{1516}$ This method determines the ratio of antibody titres against suspected intraocular pathogens in ocular fluid and serum to the total amount of IgG and is helpful in confirming the diagnosis of toxoplasma uveitis and acute retinal necrosis syndrome. ${ }^{15-20}$ In AIDS patients, the detection of CMV DNA using the polymerase chain reaction (PCR) technique might be more suited to confirm a clinical CMV retinitis than local antibody production analysis since the PCR technique does not depend upon an immunological response of the host, which is impaired in the later stages of AIDS. ${ }^{21}$ Several authors have reported herpesvirus DNA detection in ocular fluids of patients with an active CMV retinitis using the PCR technique. ${ }^{22-24}$

Assays based on the PCR are yet to be introduced in routine diagnostics of uveitis but before its general use can be accepted, the validity of the technique and the interpretation of the test results have to be analysed. The purpose of this study was to determine the value of the PCR technique as a diagnostic tool in confirming the diagnosis of CMV retinitis compared with the analysis of locally produced antibodies by calculating a GWq for ocular fluids of AIDS patients with a clinically diagnosed CMV retinitis under antiviral therapy.

\section{Materials and methods}

\section{PATIENTS}

With the patients' informed consent and according to the World Medical Association declaration of Helsinki, 1964, undiluted ocular fluid samples of two groups of patients were collected during therapeutic pars plana vitrectomy or by diagnostic anterior chamber paracentesis in case of a clinically undetermined feature of uveitis. The diagnosis of CMV retinitis and uveitis was based on the previously described features and made by two ophthalmologists experienced in uveitis. The diagnosis of AIDS was made according to the definition of the Centers for Disease Control. ${ }^{25}$ All patients had serum anti-HIV antibodies, had suffered from multiple opportunistic infections, and had CD4 + cell counts less than $400 \times 10^{6} / 1$.

In group A, 11 samples of undiluted ocular fluid from 11 eyes were obtained from nine consecutive, unselected AIDS patients with a clinical CMV retinitis. At an inactive stage, eight samples of vitreous fluid and one sample of subretinal fluid were obtained at vitrectomy required for retinal detachment. Aqueous humour was obtained from two eyes for diagnostic purposes at an active stage of the disease. The samples were directly split into two portions. One was used for antibody analysis and the other was used for DNA isolation. Serum samples for antibody analysis were obtained from all nine AIDS patients.

In group B, 10 split samples of undiluted ocular fluid obtained from 10 patients with the clinical features of an active uveitis not suspect for herpetic aetiology served as controls. Group B included patients with a low grade endophthalmitis $(n=3)$, Behçet's disease, uveitis posterior $(n=3)$, toxoplasma uveitis, non-Hodgkin's lymphoma associated uveitis, and a candida retinitis. Vitreous fluid samples were obtained from eight patients and aqueous humour samples were obtained from two patients. Serum samples were obtained from all 10 patients. Additionally, 17 samples of aqueous fluid obtained at cataract surgery of otherwise healthy individuals were only analysed by PCR assays. To establish a possible CMV viraemia an EDTA blood sample was collected from all patients and analysed for the presence of CMV DNA by PCR.

\section{DNA EXTRACTION AND PCR}

To enhance the efficacy of the PCR assay we purified the target DNA from both ocular fluid and blood samples. ${ }^{142627}$ Briefly, DNA was extracted from $100 \mu \mathrm{l}$ of undiluted ocular fluid stored in $1 \mathrm{ml}$ lysis buffer A (4 M guanidineiso-thiocyanate/0.1 M Tris- $\mathrm{HCl} \mathrm{pH} 6 \cdot 4 / 44$ mM EDTA $/ 2.5 \mathrm{ml}$ per $100 \mathrm{ml}$ Triton X100).$^{28}$ A total of $40 \mu$ l Celite solution $(2 \mathrm{~g} / \mathrm{ml}$, Jansen Chemika, the Netherlands) was added and the suspension was incubated for 10 minutes at room temperature to adsorb the DNA. The Celite pellet was washed twice with lysis buffer B (4 M guanidine-isothiocyanate/0.1 M Tris- $\mathrm{HCl} \mathrm{pH} 6 \cdot 4$ ), twice with $70 \%$ ethanol, and once with acetone. The pellet was dried for 15 minutes in a vacuum exsiccator and resuspended in $200 \mu l$ water at $56^{\circ} \mathrm{C}$. After 2 minutes of centrifugation $(15000 \mathrm{~g}), 180 \mu \mathrm{l}$ of the supernatant containing the DNA was collected.

A volume of $500 \mu \mathrm{l}$ of the EDTA blood samples was suspended in $9.5 \mathrm{ml}$ lysis buffer A. The DNA was isolated, using $300 \mu l$ of this suspension, by means of a phenol/ chloroform/isoamyl alcohol extraction and ethanol precipitation. The DNA pellet was resuspended in $200 \mu$ l water.

The PCR assays were performed detecting DNA from CMV, HSV-1, VZV, Epstein-Barr virus (EBV), and a human $\beta$ globin sequence. The PCR assay detecting the human $\beta$ globin sequence was used to verify the integrity of the target DNA and the yield of extraction method. The sequences of the primers and probes for CMV, HSV-1, VZV, and $\beta$ globin have been published previously. ${ }^{24}$ 29-32 For detection of the HSV-1 DNA, the outer primers were used. For the CMV primers we used a single base modification of the originally published sequence of the $3^{\prime}$-primer in which at the $3^{\prime}$-terminal end, a 
Table 1 Clinical data of cytomegalovirus (CMV) retinitis patients (group A) and control uveitis patients (group B)

\begin{tabular}{|c|c|c|c|c|c|c|c|}
\hline $\begin{array}{l}\text { Patient } \\
\text { No }\end{array}$ & $\begin{array}{l}\text { Sex, } \\
\text { age (years) }\end{array}$ & Initial diagnosis & $\begin{array}{l}\text { Ocular } \\
\text { fluid }\end{array}$ & $\begin{array}{l}\text { First ocular } \\
\text { appearance }\end{array}$ & $\begin{array}{l}\text { Medication } \\
\text { started }^{\star}\end{array}$ & Medication & $\begin{array}{l}\text { CD4+ cells } \\
\left(\times 10^{6} /\right)\end{array}$ \\
\hline \multicolumn{8}{|c|}{ Group A: } \\
\hline 1 & $\mathrm{M}, 61$ & CMV retinitis & Aqu & 2 & $3 / 4$ & Ganciclovir/foscarnet & 30 \\
\hline $2 \mathbf{R}$ & $\mathrm{M}, 40$ & CMV retinitis & Vit & 5 & $5^{2}$ & Ganciclovir & 10 \\
\hline $2 \mathrm{~L}$ & & CMV retinitis & Vit & 1 & 6 & Ganciclovir & 10 \\
\hline 3 & M, 35 & CMV retinitis & SRF & 5 & 5 & Ganciclovir & 40 \\
\hline 4 & $M, 38$ & CMV retinitis & Vit & 7 & 7 & Ganciclovir & $<400$ \\
\hline 5 & $M, 42$ & CMV retinitis & Vit & 2 & 2 & Foscarnet/acyclovir & 80 \\
\hline 6 & $M, 36$ & CMV retinitis & Vit & 5 & 5 & Ganciclovir/acyclovir & 10 \\
\hline 7 & $M, 29$ & CMV retinitis & Aqu & $1 / 2$ & $1 / 4$ & Ganciclovir & 20 \\
\hline $\mathbf{8 R}$ & $\mathrm{M}, 50$ & CMV retinitis & Vit & $6^{2}$ & $6^{4}$ & Foscarnet & 10 \\
\hline $8 \mathrm{~L}$ & & CMV retinitis & Vit & 6 & 6 & Foscarnet & 10 \\
\hline 9 & F, 34 & CMV retinitis & Vit & 2 & 2 & Ganciclovir & $<10$ \\
\hline \multicolumn{8}{|c|}{ Group B: } \\
\hline 1 & $\mathrm{M}, 75$ & Low grade endophthalmitis & Vit & 18 & Periodic & Steroids/antibiotics & - \\
\hline 2 & $F, 72$ & Candida retinitis & Vit & $1 / 4$ & Continuous $/ 1 / 4$ & Steroids/antimycotics & - \\
\hline 3 & $\mathrm{~F}, 57$ & Low grade endophthalmitis & Vit & $1 / 2$ & $1 / 4$ & Antibiotics & - \\
\hline 4 & M, 66 & Uveitis posterior & Vit & 5 & Periodic & Steroids & - \\
\hline 5 & M, 26 & Uveitis posterior & Vit & 24 & Periodic & Steroids & - \\
\hline 6 & $\mathrm{~F}, 43$ & Low grade endophthalmitis & Vit & 8 & Periodic & Steroids & - \\
\hline 7 & F, 58 & Non-Hodgkin's retinitis & Aqu & 2 & - & Radiotherapy & - \\
\hline 8 & F, 29 & Uveitis posterior & Vit & 18 & Periodic & Steroids & - \\
\hline 9 & M, 53 & Toxoplasma uveitis & Aqu & 2 & $2 / 1 / 4$ & Steroids/pyrimethamine & - \\
\hline 10 & $M, 37$ & Behçet's disease & Vit & 12 & - & Photolaser coagulation & - \\
\hline
\end{tabular}

ॠMonths before sampling. Aqu=aqueous fluid; Vit=vitreous fluid; $S R F=$ subretinal fluid; -=not done.

guanidine base was replaced by a cytosine base (3'-primer CGTTTGGGTTGCGCAG-CGGG). ${ }^{24}$ The sequences of the primers and probe detecting the BamHI-W fragment of the EBV genome are: 5'-primer CTCTCTCTGTCCTTCAGAGG, 3'-primer GTGGCTCCCCTCAGACATTC, and the probe AACCAGGGACCTCGGGCACCCCAGAGCCCC.

A total volume of $100 \mu \mathrm{l}$ reaction mix contained $10 \mu \mathrm{l}$ of the DNA isolate, $50 \mathrm{pmol}$ of each primer, $200 \mu \mathrm{M}$ of each desoxynucleotide triphosphate, $50 \mathrm{mM} \mathrm{KCl}, 10 \mathrm{mM}$ Tris- $\mathrm{HCl}$ pH 9.0, $2 \cdot 5 \mathrm{mM} \mathrm{MgCl}_{2}, 0 \cdot 01 \%$ gelatine, $0 \cdot 1 \%$ Triton X-100, and 1 U Taq DNA- polymerase (Promega). The PCR was processed using a Thermocycler 60/2 (Biomed, Germany). The processing conditions for all assays were preheating for 4 minutes at $94^{\circ} \mathrm{C}$, denaturation for 1 minute at $94^{\circ} \mathrm{C}$, annealing for 1 minute at $52^{\circ} \mathrm{C}$, and elongation for 1 minute at $74^{\circ} \mathrm{C}$, repeating a total of 40 cycles except for the CMV assay which was annealed for 30 seconds at $48^{\circ} \mathrm{C}$. Twenty five $\mu l$ of the amplimers were electrophoresed on a $3 \%$ agarose gel. The gel was electroblotted to a Hybond $\mathrm{N}+$ membrane (Amersham) at $3.5 \mathrm{~mA} / \mathrm{cm}^{2}$ for 35 minutes. The membranes were hybridised with ${ }^{32} \mathrm{P}$ ATP-labelled oligonucleotides. After overnight incubation at $37^{\circ} \mathrm{C}$, the membrane was washed twice for 15 minutes with $2 \times \mathrm{SSC} / 0 \cdot 1 \%$ SDS and once with $0.5 \times \mathrm{SSC} / 0.1 \%$ SDS for 15 minutes at $56^{\circ} \mathrm{C}(1 \times S S C$ is $15 \mathrm{mM}$ sodium citrate, $150 \mathrm{mM} \mathrm{NaCl}$ ). Finally, an autoradiographic film was exposed for $4 \cdot 5$ hours.

A sample of double distilled water going through the extraction procedure and the PCR, and a second sample of double distilled water only going through the PCR served as negative controls. DNA extracted from cell lines infected with CMV, HSV-1, VZV, or EBV served as positive controls.

\section{ANTIBODY ANALYSIS}

Analysis of IgG class antibody titres against the herpesviruses on a paired serum and ocular fluid sample was performed by using a fixed cell immunofluorescence technique as described by Luyendijk et al. ${ }^{20}$ The total amount of IgG in serum and ocular fluid was determined by a radial immunodiffusion technique. Antibodies were detected on twofold serial dilutions of the ocular fluid samples and of the serum samples. A GWq was calculated and considered significant if above $3 \cdot 0$.

\section{Results}

Group A included nine AIDS patients with the clinical diagnosis of CMV retinitis (Table 1). Their mean age was 41 ( range 29-41) years. The mean duration of ocular symptoms until obtaining the ocular fluid sample was 3.8 (range $1 / 2-7$ ) months. Eight patients were diagnosed having an unilateral CMV retinitis and one patient was diagnosed having a bilateral CMV retinitis. In one patient (A8, Table 1) a bilateral CMV retinitis became apparent 1 month after obtaining the sample from the first affected eye. All nine patients in group A had received antiviral therapy before obtaining the sample with a mean of 4.0 months (range 4 days -6 months). All AIDS patients had CD4+ counts less than 50 cells $\times 10^{6} / 1$ except for patient A4, who was suffering from AIDS and non-Hodgkin's lymphoma, and patient A5.

The patients of the control group B had a mean age of 52 (range 26-75) years (Table 1). They did not receive antiviral therapy during the course of disease. Patient B2 had received continuous steroid therapy. Five patients (B1, B4, B5, B6, B8, Table 1) intermittently received steroid therapy in case of exacerbation of the ocular inflammation. One patient, B7, was treated with radiotherapy and patient B8 received pyrimethamine, an antiprotozoic agent.

Eleven ocular fluid samples of group A patients were analysed for the presence of DNA sequences of the herpesviruses and the human $\beta$ globin gene (Table 2). In 10 of 11 samples CMV DNA was detected. One sample was positive for both CMV and VZV DNA (A5) and another (A6) was only positive for VZV DNA. Genomic DNA from EBV or HSV-1 was not detected in any of the 11 
Table 2 Summary of the results of the polymerase chain reaction assays and GoldmannWitmer quotients on ocular fluids and serum samples of group $A$ and group $B$

\begin{tabular}{|c|c|c|c|c|c|c|}
\hline \multirow{2}{*}{$\begin{array}{l}\text { Patient } \\
\text { No }\end{array}$} & \multirow{2}{*}{$\begin{array}{l}C M V \\
D N A \\
\text { in blood }\end{array}$} & \multirow{2}{*}{$\begin{array}{l}\text { Ocular fluid } \\
\text { DNA positive } \\
\text { for }\end{array}$} & \multicolumn{4}{|c|}{ Goldmann-Witmer quotient ${ }^{\star}$} \\
\hline & & & $C M V$ & $H S V-1$ & $V Z V$ & $E B V$ \\
\hline \multicolumn{7}{|l|}{ Group A: } \\
\hline $2 \mathrm{R}$ & Pos & CMV & $1 \cdot 0$ & $1 \cdot 0$ & $1 \cdot 0$ & $\overline{1} \cdot 0$ \\
\hline $2 \mathrm{~L}$ & Pos & CMV & - & - & - & - \\
\hline 3 & & CMV & - & - & - & - \\
\hline 4 & Pos & CMV & $<1$ & $<1$ & $<1$ & $<1$ \\
\hline 5 & - & CMV/VZV & $1 \cdot 0$ & $1 \cdot 2$ & $<1$ & - \\
\hline 6 & - & VZV & $1 \cdot 2$ & $<1$ & $<1$ & $1 \cdot 2$ \\
\hline 7 & Pos & $\mathrm{CMV}$ & $4 \cdot 0$ & $8 \cdot 0$ & 31.9 & $<1$ \\
\hline $8 \mathbf{R}$ & Pos & $\mathrm{CMV}$ & $<1$ & $<1$ & $<1$ & $<1$ \\
\hline $8 \mathrm{~L}$ & Pos & CMV & $<1$ & $<1$ & $<1$ & $<1$ \\
\hline 9 & - & $\mathrm{CMV}$ & $-t$ & $<1$ & $<1$ & $1 \cdot 1$ \\
\hline \multicolumn{7}{|l|}{ Group B: } \\
\hline 1 & - & HSV-1 & $<1$ & $1 \cdot 2$ & $<1$ & - \\
\hline 2 & - & - & $<1$ & $6 \cdot 4$ & $-\dagger$ & $1 \cdot 0$ \\
\hline $\begin{array}{l}3 \\
4\end{array}$ & - & - & $\overline{1} \cdot 8$ & $\begin{array}{l}1 \cdot 1 \\
0\end{array}$ & $\begin{array}{l}8.4 \\
<1\end{array}$ & $<1$ \\
\hline 5 & - & - & - & 1.6 & $-t$ & $-t$ \\
\hline 6 & - & - & - & $<1$ & $-t$ & $-t$ \\
\hline 7 & - & - & 1.9 & $<1$ & $<1$ & $<1$ \\
\hline 8 & - & - & $-t$ & $1 \cdot 6$ & ${ }_{-1}^{-\dagger}$ & ${ }_{<1}^{-\dagger}$ \\
\hline 9 & - & $=$ & $-t$ & $<1$ & $<1$ & $<1$ \\
\hline 10 & - & - & $-T$ & $2 \cdot 7$ & $2 \cdot 7$ & $2 \cdot 7$ \\
\hline
\end{tabular}

$\mathrm{CMV}=$ cytomegalovirus; $\mathrm{HSV}=$ herpes simplex virus; $\mathrm{VZV}=$ varicella zoster virus; $\mathrm{EBV}=$ Epstein-Barr virus

*A Goldmann-Witmer quotient of 3.0 or more is considered significant. †Not calculable owing to a negative antibody titre in serum and/or ocular fluid. $-=$ Not done. $R=$ right eye; $L=$ left eye.

samples. In all samples the human $\beta$ globin DNA sequence could be detected.

The blood samples of the CMV retinitis patients showed detectable CMV DNA in four patients (A2, A4, A7, A8, Table 2). In two patients, two blood samples were examined for CMV DNA over a time span of 1 month. In both cases the first and second sample were CMV DNA positive despite antiviral medication.

The ocular fluid samples of the control group B showed no detectable CMV, VZV or EBV DNA (Table 2). In one of 10 samples, HSV-1 DNA was detected (B1). No CMV DNA was detected in the whole blood samples of the control group B. In the aqueous of the 17 cataract patients no herpesvirus DNA was detected. In all control samples the $\beta$ globin DNA was detected.

Table 3 Serological data on ocular fluid samples from cytomegalovirus (CMV) retinitis patients, group $A$ and uveitis control patients, group $B$

\begin{tabular}{|c|c|c|c|c|c|c|c|c|}
\hline \multirow{2}{*}{$\begin{array}{l}\text { Patient } \\
\text { No }\end{array}$} & \multicolumn{4}{|c|}{ Serum antibody titre (1:titre) } & \multicolumn{4}{|c|}{ Ocular fluid antibody titre (1:titre) } \\
\hline & $C M V$ & $H S V-1$ & $V Z V$ & $E B V$ & $C M V$ & $H S V-1$ & $V Z V$ & $E B V$ \\
\hline \multicolumn{9}{|c|}{ Group A: } \\
\hline & $\begin{array}{r}64 \\
128\end{array}$ & $\begin{array}{l}1024 \\
1024\end{array}$ & $\begin{array}{l}256 \\
512\end{array}$ & $\begin{array}{r}2048 \\
256\end{array}$ & $\begin{array}{r}<4 \\
8\end{array}$ & $\frac{-}{64}$ & $\overline{16}$ & $\overline{16}$ \\
\hline $2 \mathrm{~L}$ & 120 & 1024 & - & - & - & - & 10 & 10 \\
\hline 3 & - & - & - & - & - & - & - & - \\
\hline 4 & 256 & 1024 & 1024 & 2048 & 16 & 128 & 128 & 512 \\
\hline 5 & 1024 & 1024 & 128 & - & 32 & 64 & 4 & - \\
\hline 6 & 64 & 2048 & 64 & 1024 & 16 & 256 & 8 & 256 \\
\hline 7 & 256 & 512 & 256 & 1024 & 2 & 8 & 16 & 2 \\
\hline $8 R$ & 256 & 2048 & 512 & 512 & 8 & 64 & 16 & 16 \\
\hline $8 \mathrm{~L}$ & 256 & 1024 & 1024 & 4096 & 16 & 64 & 16 & 64 \\
\hline 9 & 16 & 2048 & 256 & 64 & 0 & 32 & 4 & 2 \\
\hline \multicolumn{9}{|c|}{ Group B: } \\
\hline 1 & 1024 & 1024 & 128. & - & 32 & 64 & 4 & - \\
\hline 2 & 512 & 16 & - & 256 & 8 & 2 & 0 & 16 \\
\hline 3 & - & 64 & 16 & - & - & 2 & 4 & - \\
\hline 4 & 64 & $<16$ & 256 & 1024 & 8 & 0 & 16 & 64 \\
\hline 5 & - & 2048 & 256 & 256 & - & 8 & 0 & 0 \\
\hline 6 & - & 1024 & 256 & 256 & - & 128 & 0 & 0 \\
\hline 7 & 64 & 1024 & 64 & 64 & 8 & 4 & 4 & 64 \\
\hline 8 & 32 & 2048 & 1024 & 1024 & 0 & 8 & 0 & 0 \\
\hline 9 & 16 & 256 & 1024 & 64 & 0 & 8 & 8 & 2 \\
\hline 10 & 256 & 64 & 256 & 256 & 0 & 2 & 8 & 8 \\
\hline
\end{tabular}

$\mathrm{HSV}=$ herpes simplex virus; $\mathrm{VZV}=$ varicella zoster virus; $\mathrm{EBV}=$ Epstein-Barr virus. $-=$ Not done. $R=$ right eye; $L=$ left eye.
All the analysed sera and the ocular fluid samples of group A patients had positive antibody titres against $\mathrm{HSV}-1, \mathrm{VZV}$, and EBV (Table 3). In eight of nine (89\%) tested ocular fluid samples, IgG anti-CMV antibodies were detected. The GWq was calculated on nine samples of ocular fluid of group A for CMV, HSV-1, and VZV. A GWq for EBV was calculated on seven samples. In sample A7, a significant GWq was found for $\mathrm{CMV}$ as well as for HSV-1 and VZV (Table 2). None of the samples of group A had a significant GWq for any of the tested herpesviruses although intraocular antibodies against herpesviruses were present (Table 3).

In the control group B, paired serum and ocular fluid samples were obtained from all 10 patients. Patient B4 had a serum titre lower than 1:16 for HSV-1 (Table 3). All other patients tested had positive serum antibody titres for all herpesviruses - that is, equal or larger than 1:16. In group $B$, four of seven $(57 \%)$ ocular fluid samples tested for CMV had a positive antibody titre. For HSV-1 this was nine of $10(90 \%)$, for VZV six of 10 $(60 \%)$, and for EBV this was five of eight $(63 \%)$. No sample of the control group B showed a significant GWq for CMV and EBV. One sample (B2) showed a significant GWq for HSV-1. Another sample (B3) showed a significant GWq for VZV (Table 2).

\section{Discussion}

This report compares the results of analysis of local antibody production against herpesviruses and PCR assays, detecting DNA of herpesviruses in ocular fluid, in relation to the clinical diagnosis of $\mathrm{CMV}$ retinitis in unselected cases in AIDS patients. The clinical diagnosis could not be confirmed in nine of the tested cases by a significant GWq. Compared with the PCR assays the clinical diagnosis of CMV retinitis showed a sensitivity of $100 \%$ and a specificity of $91 \%$.

In comparing both types of assays one should consider the basic differences in technique. The PCR assay is a test, detecting directly a part of the virus. The analysis of antibody production, however, is an indirect test, depending on an immunological response of the host against the virus, which is normally reflected in a rise of the antibody titre, but affected in AIDS patients.

The results of the very specific and sensitive PCR technique require a well balanced interpretation, especially in analysing viruses of the herpes family such as CMV, HSV-1, VZV, and EBV. These viruses can establish latent infections in humans and since all patients tested have detectable serum IgG antibodies against all herpesviruses, except patient B4, who had an antibody titre less than 1:16 for HSV-1, they are expected to be carriers of these viruses. However, the aqueous samples of 17 cataract patients were all negative for herpesvirus DNA, indicating that normally no herpesvirus is present in ocular fluid of non-inflamed eyes. 
An inflammatory reaction as in uveitis can be a trigger for secondary release of latent herpesviruses and lead to clinically false positive PCR results if detection of the primary pathogen is intended. In ocular fluids from the uveitis control patients, no DNA from the neurotrophic latent $V Z V$ or the lymphocytotrophic latent EBV and CMV was detected. This indicates that no positive PCR results were caused by herpesviruses released from latently infected sensory nerve endings, lymphocytes, or vascular endothelium cells.

In group $A$ the role of $\mathrm{VZV}$ as a co-infectant or primary pathogen was anticipated. In patient A5, for instance, both CMV DNA and VZV DNA were detected. The ophthalmoscopic features were, however, indicative of a CMV retinitis and lacked a pronounced retinal necrosis. Sample A6, on the other hand, was CMV DNA negative but VZV DNA was positive. In this case, ophthalmoscopic and clinical features were indecisive. The results of the PCR assays indicated an acute retinal necrosis syndrome was more likely and after additive acyclovir therapy the process was halted temporarily. In one uveitis control sample (B1), HSV-1 DNA was found and secondary HSV release must be considered. This patient was suffering from a recurrently eliciting iridocyclitis and a low grade endophthalmitis for 1.5 years after a cataract extraction with lens implantation. Initially, the inflammation responded well to antibiotic and steroid therapy. Later, removal of the implant lens and vitrectomy were necessary. Bacterial cultures of the vitreous fluid were negative and the GWq for CMV, HSV-1, and VZV were insignificant. The insignificant $\mathrm{GWq}$ for HSV-1 can be due to wrong time of sampling or to extinction of the immune response after frequent stimulation leading to an absence in rise in antibody production, especially of the IgG class, as has been documented in patients repeatedly suffering from recurrent herpetic infections. ${ }^{18} 33$

In AIDS patients a CMV viraemia with leakage of viral particles through the bloodretinal barrier might lead to clinically false positive PCR results in ocular fluid. To exclude this, detection of CMV DNA in blood served as a control. Five out of nine blood samples of group A were CMV DNA negative indicating that CMV DNA in the paired ocular fluid did not originate from the blood. Regarding the paired samples being obtained several weeks after onset of the CMV retinitis the results do not exclude intraocular CMV particles originating from a previous viraemia. It is, however, remarkable that despite prolonged intravenous antiviral therapy four blood samples were CMV DNA negative whereas the corresponding ocular fluid samples were positive and retrospectively confirming the clinical diagnosis. Since clearance of the virus is not only depending on virustatic therapy but also on a functional immune response, the absence of CMV DNA in these blood samples might reflect a residual immune function (three of the four patients had CD4+ counts between 30 and 80 cells $\left.\times 10^{6} / 1\right)$ combined with a poor penetration of the antiviral medication through the bloodretinal barrier. Resolution of detectable CMV DNA in blood after antiviral therapy has been reported earlier. ${ }^{14}$

Control uveitis samples showed no significant GWq for CMV and thus no false positive results were found. In group $\mathrm{A}$ also no confirmation of the initial diagnosis of CMV retinitis was demonstrated by a positive GWq. Although minimal use of antibody based assays in AIDS patients might be expected, all but one ocular fluid sample of AIDS patients proved to contain CMV DNA and anti-CMV antibodies, and all sera were anti-CMV IgG or CMV DNA positive or both. Theoretically an inconclusive GWq must result from the insufficient absolute or relative rise of local antibody production. In group A cases an insufficient absolute rise of local antibody production against CMV is likely to be caused by an impaired antibody production as has been described in the later stage of AIDS, both in quantity and quality, and in cytotoxic reaction. ${ }^{21}$ This can be expected because of the low CD4+ counts. An insufficient relative rise in local antibody production can result from leakage of antibodies through the blood-retinal barrier due to a destructive inflammatory reaction. Furthermore, an overwhelming presence of antigen in the eye might capture the intraocular antibodies, restraining them from analysis. The ratio of antibody titres in calculating a GWq can further be disturbed by relatively high serum IgG antibody titres against $\mathrm{CMV}$, caused by an actual or recent CMV viraemia and high total IgG levels, as is frequently observed in AIDS patients. ${ }^{21}$ Confusingly, sample A7 showed a significant GWq for CMV, HSV-1, and VZV whereas only CMV DNA was found. Here a possibly aspecific polyclonal antibody production or a co-infection might have led to an indecisive GWq. ${ }^{18}$

Two samples of the control group (B2, B3) showed a significant $\mathrm{GWq}$, indicating a possible pathogenic role for these viruses. Patient B2 showed a significant GWq for HSV-1 but the PCR assay was negative. This patient was suffering from a systemic lupus erythematosus and was treated continuously with prednisone. A vitrectomy was performed and vitreous fluid was cultured and found positive for Candida tropicalis, which responded well to antimycotic therapy. A significant GWq for VZV was found in a patient (B3) suffering from a low grade endophthalmitis for 1 month after cataract extraction with lens implantation which responded well to antibiotic therapy. Vitreous fluid was culture positive for Staphylococcus epidermidis. A relapse 3 weeks after surgery was treated successfully with acyclovir as aqueous showed a significant GWq for VZV. A second relapse occurred within a week after cessation of acyclovir therapy. Removal of the intraocular implant lens prevented further relapses. The absence of viral DNA seems similar to the negative PCR results in the course of herpes 
simplex encephalitis, perhaps as a result of late timing of obtaining the sample, especially when it concerns immune competent patients basically capable of clearing the virus. ${ }^{34}$

In conclusion, ophthalmoscopic examination is a sensitive method for the clinical diagnosis of CMV retinitis in unselected cases in AIDS patients. In indistinctive cases confirmation of the diagnosis of $\mathrm{CMV}$ retinitis by detecting CMV DNA in ocular fluid using a PCR assay is a more sensitive tool than analysis of locally produced antibodies. The herpesvirus PCR assays can support the choice of therapy in atypical clinical cases. In the case of a clinical non-herpetic, active uveitis the role of secondary released HSV-1 or VZV should be considered, possibly requiring additional therapeutic anticipation. Since no postoperative complications were observed, anterior chamber paracentesis is a safe method to obtain clinical samples for laboratory analysis.

In future studies, the value of PCR assays for other aetiological agents in infectious uveitis and other patient groups must be established. Moreover, efforts should be made to enhance the efficacy of the PCR assays in ophthalmology, and to develop standardised protocols and intercentre quality control programmes allowing better comparison of the results of different studies.

1 Burns RP. Cytomegalic inclusion disease uveitis. Report of a case with isolation from aqueous humor of the virus culture. Arch Ophthalmol 1959; 61: 376-87.

2 Friedman AH, Orellana J, Freeman WR, Luntz MH, Starr MB, Tapper ML, et al. Cytomegalovirus retinitis: a manifestation of the acquired immune deficiency syndrome (AIDS). Br f Ophthalmol 1983; 67: 372-80.

3 Pepose JS, Hilborne LH, Cancilla PA, Foos RY. Concurrent herpes simplex and cytomegalovirus retinitis and encephalitis in the acquired immune deficiency syndrome (AIDS). Ophthalmology 1984; 91: 1669-77.

4 Pepose JS, Holland GN, Nestor MS, Cochran AJ, Foos RY. Acquired immune deficiency syndrome: pathogenic mechanisms of ocular disease. Ophthalmology 1985; 92: 472-84.

5 Aaberg TM, Cessarz TJ, Rytell MW. Correlation of virology and clinical course of cytomegalovirus retinitis. $\mathrm{Am} \mathscr{f}$ Ophthalmol 1972; 74: 407-15.

6 Berger BB, Weinberger RS, Tessler HA, Wyhinny GJ, Vygantas $M$. Bilateral cytomegalovirus pan-uveitis after high dose corticosteroid therapy. Am $₹$ Ophthalmol 1979, 88: $1020-5$.

7 De Venecia G, Zu Rhein GM, Pratt MV, Kisken W. Cytomegalic inclusion retinitis in an adult. Arch Ophthalmol 1971; 86: 44-57.

8 Murray HW, Knox DL, Green WR, Susel RM. Cytomegalovirus retinitis in adults. $A m \mathcal{f}$ Med 1977; 63: 574-83.

9 England AC, Miller SA, Maki DG. Ocular finding of acute cytomegalovirus infection in an immunologically competent adult. $N$ Engl f Med 1982; 307: 94-5.

10 Chawla HB, Ford MJ, Munro JF, Scorgie RE, Watson AR. Ocular involvement in cytomegalovirus infection in a previously healthy adult. $B r M e d ~ \Im 1976 ; 196: 281-2$.

11 Freeman WR, Lerner CW, Mines JA, Lash RS, Nadel AJ, Starr MB, et al. A prospective study of the ophthalmological findings in the acquired immune deficiency syndrome. Am $\mathrm{f}$ Ophthalmol 1984; 97: 133-42.

12 Holland GN, Gottlieb MS, Yee RD, Schanker HM, Petti TH. Ocular disorders associated with a new severe acquired cellular immunodeficiency syndrome. $A m$ Ophthalmol 1982; 93: 393-492.

13 Lewandowski R, Deschênes J, Cabrera A, Goldstein D,
Burnier MN. Multiple ocular infections in AIDS patients. Invest Ophthalmol Vis Sci 1994; 35 (suppl): 1310.

14 Gerna G, Baldanti F, Sarasini A, Furione M, Percivalle E Revello MG, et al. Effect of foscarnet induction treatment on quantitation of human cytomegalovirus (HCMV) DNA in peripheral blood polymorphonuclear leucocytes and aqueous humor of AIDS patients with HCMV retinitis. Antimicrob Agents Chemother 1994; 38: 38-44.

15 Dussaix E, Cerqueti PM, Pontet F, Bloch-Michel E. New approaches to the detection of locally produced antiviral antibodies in the aqueous humor of patients with endogenous uveitis. Ophthalmologica 1987; 194: 145-9.

16 Pepose JS, Flowers B, Stewart JA, Grose C, Levy DS Pepose JS, Flowers B, Stewart JA, Grose C, Levy DS, etiologic diagnosis of the acute retinal necrosis syndrome. Am F Ophthalmol 1992; 113: 248-56.

17 Baarsma GS, Luyendijk L, Kijlstra A, de Vries J, Peperkamp E, Mertens DAE, et al. Analysis of local antibody production in the vitreous humor of patients with severe uveitis. Am ₹ Ophthalmol 1991; 112: 147-50.

18 De Boer JH, Luyendijk L, Rothova A, Baarsma GS, de Jong PTVM, Bollemeyer JG, et al. Detection of intraocular antibody production to herpesviruses in acute retinal antibody production to herpesviruses in acute retinal

19 Kijlstra A, Breevaart AC, Baarsma GS, Bos PJM, Rothova A, Luyendijk L, et al. Aqueous chamber taps in toxoplasmic chorioretinitis. Doc Ophthalmol 1986; 64: 53-8.

20 Luyendijk L, van der Horn GJ, Visser OH, SuttorpSchulten MS, van der Biesen PR, Rothova A, et al. Detection of locally produced antibodies to herpes viruses in the aqueous of patients with acquired immune in the aqueous of patients with acquired immune (ARN). Curr Eye Res 1990; 9 (suppl): 7-11.

21 Converse PJ, Fehniger TE, Strannegard O, Britton S Immune responses to fractionated cytomegaloviru (CMV) antigens after HIV infection. Loss of cellular and humoral reactivity to antigens recognized by HIV-, CMV+ individuals. Clin Exp Immunol 1990; 82: 559-66.

22 Michell SM, Fox JD, Tedder RS, Gazzard BG, Lightman S Vitreous fluid sampling and viral genome detection for the diagnosis of viral retinitis in patients with AIDS. $\mathcal{f}$ Med Virol 1994; 43: 336-40.

23 Fenner TE, Garweg J, Hufert FT, Boehnke M, Schmitz H. Diagnosis of human cytomegalovirus-induced retinitis in human immunodeficiency virus type 1-infected subjects by using the polymerase chain reaction. $f$ Clin Microbio 1991; 29: 2621-2.

24 Fox GM, Crouse CA, Chuang EL, Pflugfelder SC, Cleary TJ, Nelson SJ, et al. Detection of herpesvirus DNA in vitreous and aqueous specimen by polymerase chain reaction. Arch Ophthalmol 1991; 109: 266-71.

25 Centers for Disease Control. Revision of the CDC surveillance case definition for acquired immunodeficiency syndrome. $M M W R$ 1987; 36 (suppl): 1-15

26 Biswas J, Mayr AJ, Martin WJ, Rao NA. Detection of human cytomegalovirus in ocular tissue by polymerase chain reaction and in situ DNA hybridization. Graefes Arch Clin Exp Ophthalmol 1993; 231: 66-70.

27 Wiedbrauk DL, Werner JC, Drevon AM. Inhibition of the polymerase chain reaction by aqueous and vitreous fluid. Invest Ophthalmol Vis Sci 1994; 35 (suppl): 1688.

28 Boom R, Sol CJA, Salimans MMM, Jansen CL Wertheim-van Dillen PME, van der Noordaa J. Rapid and simple method for purification of nucleic acids. $f$ Clin Microbiol 1990; 28: 495-503.

29 Aurelius E, Johansson B, Sköldenberg B, Staland A Forsgren M. Rapid diagnosis of herpes simplex encephalitis by nested polymerase chain reaction assay of cerebrospinal fluid. Lancet 1991; 337: 189-92.

30 Crouse CA, Pflugfelder SC, Pereira I, Cleary T, Rabinowit $S$, Atherton SS. Detection of herpes viral genomes in normal and diseased corneal epithelium. Curr Eye Res 1990; 9: 569-81.

31 Dlugosch D, Eis-Hübringer AM, Kleim J-P, Birehoff E, $\mathrm{Schneweis} \mathrm{KE}$. Diagnosis of acute and latent varicellazoster virus infections using the polymerase chain reaction. F Med Virol 1991; 35: 136-41.

32 Saiki RK, Scharf S, Faloona F, Mullis KB, Horn GT, Erlich $\mathrm{HA}$, et al. Enzymatic amplification of $\beta$-globin genomic sequences and restriction site analysis for detection of sequences and restriction site analysis for
sickle cell anemia. Science $1985 ; 230: 1350-4$.

33 Juto $P$, Settergren B. Specific serum IgA, IgG and IgM antibody determination by a modified indirect ELISA technique in primary and recurrent herpes simplex infection. $\mathcal{F}$ Virol Methods 1988; 20: 45-56.

34 Puchhammer-Stöckl E, Heinz FZ, Kundi M, PopowKraupp T, Grimm G, Millner MM, et al. Evaluation of the polymerase chain reaction for diagnosis of herpes simplex virus encephalitis. F Clin Microsc 1993; 31: $146-8$. 